\title{
THE CURRENT STATE OF RESEARCH SPATIAL IMAGINATION OF THE STUDENTS OF THE PRIMARY SCHOOL IN THE CONTEXT OF 3D MODELING
}

\author{
Jan FADRHONC*, Západočeská univerzita v Plzni \\ Jarmila HONZÍKOVÁ, Západočeská univerzita v Plzni
}

Přijato: 24. 10. 2018 Akceptováno: 10. 1.2019

Typ článku: Výzkumný článek

DOI: $10.5507 /$ jtie.2019.002

Abstract: The article is an overview study which first introduces the reader to the conception of the planned research on the impact of the $3 D$ modeling teaching on spatial imagination. This study then introduces the current state of research on $3 D$ modeling and spatial imagination in elementary school pupils. The overview study is conceptually divided into two parts, to search of theoretical resources, which serves in particular as a support of the theoretical part and search of research articles in the databases of Web of Science and Scopus.

Key words: overview study, 3D modeling, spatial imagination.

\section{SOUČASNÝ STAV VÝZKUMŮ PROSTOROVÉ PŘEDSTAVIVOSTI U ŽÁKŮ ZŠ V KONTEXTU 3D MODELOVÁNÍ}

Abstrakt: Článek tvoři přehledová studie, která nejprve seznámi čtenáre s koncepcí plánovaného výzkumu vlivu výuky $3 D$ modelování na prostorovou představivost. Následně seznamuje s aktuálním stavem výzkumu zaměreného na $3 D$ modelováni a prostorovou predstavivost u žákỉ základních škol. Přehledová studie je konceptuálně rozdělena na dvě části, na vyhledáváni teoretických zdrojü, které slouži zejména jako opora teoretické části, a vyhledáváni výzkumných článků v databázich Web of Science a Scopus.

Klíčová slova: přehledová studie, 3D modelování, prostorová představivost.

\footnotetext{
*Autor pro korespondenci: fadrhonc@kvd.zcu.cz
} 


\section{1 Úvod}

Přehledová studie vznikla z potřeby zjištění aktuálního stavu výzkumu v oblasti 3D modelování a prostorové představivosti u žáků základních škol tak, aby bylo možné ověřit míru důležitosti výzkumu v této oblasti. V článku bude představena kompletní přehledová studie, která obsahuje dva přístupy vyhledávání podkladů. První prrístup, kde se využivá vyhledávání teoretických zdrojů, které poslouží hlavně pro vytvoření podkladů pojmů a zjištění historických kontextů. Druhý př́stup spočívá ve vyhledávání výzkumů zaměřených na 3D modelování a prostorovou představivost $\mathrm{v}$ databázích Web of Science a Scopus.

Podnětem pro výzkum a tvorbu přehledové studie byl aktuální vývoj v oblasti 3D tiskáren. 3D tiskárny se v posledních několika letech neustále zdokonalují (Krotký, Honzíková \& Moc, 2016) a současně se stávají i cenově dostupnější jak pro domácnosti, tak i pro základní školy. Právě tato dostupnost zapříčinila, že si některé základní školy začaly pořizovat právě 3D tiskárny, mnohdy pouze s malou znalostí této technologie a též s malou koncepční představou zařazení této technologie do vzdělávání, což potvrzuje i naše osobní zkušenost. (Již dvě základní školy z Plzně se na nás obrátily s prosbou o sestavení 3D tiskárny a zaškolením. Jiná s prosbou o opravu funkční, ale špatně nastavené tiskárny a další dvě $\mathrm{s}$ žádostí o pomoc při jejich výběru.)

Právě využitelnost 3D tiskáren ve výuce vnímáme jako problém. Je důležité, aby se 3D tiskárna nestala pouhou inventární položkou, proto je potřeba vědět, jak do výuky zakomponovat 3D tiskárnu jako pomůcku. V technické výchově se dá 3D tiskárna využít jako ukázka principu počítačem řízených strojů (frézek, gravírovacích laserů, atd.), toto využití je ale nedostačující a nevyužije celý potenciál dané problematiky. V optimálním případě se $\mathrm{v}$ rámci hodin informatiky a matematiky mohou žáci seznámit $\mathrm{s}$ tvorbou 3D modelů a naučit se vytvářet jednoduší i složitější 3D modely. V hodinách technické výchovy mohou žáci připravovat modely pro tisk a následně tyto modely vytisknou a zkoumat vytištěné materiály.

To, do jaké míry se výuka 3D tisku a 3D modelování bude realizovat, záleží na provázanosti předmětů, jako jsou technická výchova, matematika, informatika, výtvarná výchova a také na časové dotaci a schopnostech učitele a zejména na jeho zkušenostech v oblasti 3D tiskáren a 3D modelováni.

\section{Metody plánovaného výzkumu}

Výzkumnou metodou pro náš výzkum bude pedagogický experiment, který bude porovnávat výsledky u žáků s výukou klasickou (skupina kontrolní), která bude rozvíjet prostorovou představivost již běžnými prostředky a s výukou doplněnou o 3D modelování (skupina experimentální). Pro zjištění úrovně rozvoje prostorové představivosti, tedy pokroku jedinců, bude využit pretest a posttest. Jako nezávisle proměnná byla stanovena výuka 3D modelování podle navržené metodiky. Závisle proměnnou byl stanoven rozvoj prostorové představivosti. Potřebné skupiny, kontrolní i experimentální, budou vybrány náhodně mezi žáky na dané škole, u kterých probíhá oddělená výuka informatiky, a to ve shodném rozsahu.

Pro vyjádření očekávaného vlivu nezávisle proměnné na závislou proměnnou jsme u palovaného výzkumu stanovili základní hypotézu: „Výuka informačních technologii doplněná o část 3D modelování má větší vliv na prostorovou představivost $u$ žáků druhého stupně základních škol než výuka základní. "Výuka základní se v našem případě týká obsahu výuky na základních školách, která by měla rozvíjet prostorovou představivost 
u žáků. Může se jednat např́ílad o výuku kresby perspektivy ve výtvarné výchově, výuku počítačové grafiky $\mathrm{v}$ informatice, výuku těles v matematice, či výuku technického kreslení v technické výchově.

Měření závisle proměnné bude realizováno pomocí testu struktury inteligence I-S-T Rudolfa Amthauera. $Z$ testu bude vybrána pouze část zabývající se testováním figurální inteligence. Tento test má formu $\mathrm{A}$, která bude využita jako pretest, a formu $\mathrm{B}$, která bude využita jako posttest. Pro lepší validitu využijeme triangulaci výzkumu a jeho součástí bude pozorování žákủ a rozhovor s učiteli, př́ipadně rozbor vytvořených modelů.

\section{Klíčové otázky přehledové studie}

Na základě koncepce výzkumu jsme se museli zeptat na důležitost a významnost našeho výzkumu, proto jsme si položili následující otázky:

- Jaké impulzy byly přičinou volby řešeného tématu?

- Které pojmy jsou pro naše téma dủležité?

- Je stanovený výzkum možné provést a navazuje na nějaké předešlé?

- Jakým způsobem probíhá výzkum našeho tématu v ČR?

- Jakým způsobem probíhá výzkum našeho tématu ve světě?

- Které publikace jsou u tohoto tématu považovány za klíčové?

\section{Odpovědi na klíčové otázky přehledové studie}

Na klíčové otázky přehledové studie jsme odpovídali pomocí informací získaných z vyhledávání teoretických zdrojů a vyhledávání výzkumů v databázích Web of Science a Scopus.

\subsection{Jaké impulzy byly př́činou volby řešeného tématu?}

Odpověd' na první otázku, odkud se naše téma vzalo, dokážeme zodpovědět sami. $\mathrm{V}$ poslední době nastává boom počítačem řízených strojů $\mathrm{v}$ cenových relacích umožňující jejich nákup, tedy i jejich využitelnost, jednak v domácnostech, tak i ve vzdělávací oblasti. Jedná se většinou o menší stroje s omezenější velikostí výrobku. Mezi tyto stroje můžeme zařadit laserová gravírovací zařízení, menší frézky, soustruhy a 3D tiskárny. Právě 3D tiskárny se v posledních letech začaly objevovat na základních školách. Jejich využití právě na základních školách je samožrejmě velmi rozdílné. Můžou sloužit v podstatě jen jako reklama, jak je daná škola pokroková, ale samotné využití při výuce je mnohdy minimální a pokud nastane, sníží se na pouhou předváděcí akci. $V$ lepším př́padě jsou 3D tiskárny využívány ve výuce, at již v různých kroužcích, nebo dokonce je průkopníci a nadšenci $\mathrm{z}$ řad kantorů zařadí do již tak nabyté výuky technické výchovy nebo informatiky. Pro zařazení 3D tiskárny jako prostředku pro výuku je důležitá znalost celého procesu výroby. $\mathrm{V}$ první řadě je potřeba vytvořit $3 \mathrm{D}$ model, následuje jeho úprava a příprava pro tisk. V dalším kroku je potřeba model „,přeložit" na strojově čitelný kód, připravit tiskárnu na tisk a model vytisknout. Nás zejména zajímá samotná tvorba modelu.

Výuka 3D modelování se začala na základních školách realizovat až v posledních několika letech, a to pouze jen na malém zlomku z nich. To souvisí již s výše zmíněným boomem 3D tiskáren, ale i se vznikem a optimalizací intuitivních nástrojů pro 3D modelování. Základní škola by měla své žáky připravit do života v různých oblastech. Stále se mluví o podpoře technického vzdělávání, které pomůže připravit, ale i nadchnout žáky nebo studenty pro budoucí zaměstnání v oblasti techniky, zejména pak strojírenství. Do určité míry by zde mohla pomoci právě výuka 3D modelování. Musíme se ale ptát, zda 
je pro tuto výuku vhodná právě cílová skupina žáků základní školy. To lze zjistit samožrejmě otestováním, např́klad pomocí didaktických testů do jaké míry se v oblasti modelování $\mathrm{v}$ daném prostředí zlepšili. To je samožrejmě, alespoň pro nás, ta jednodušší cesta, která má poměrně jasný výsledek. Ta složitější cesta spočívá v otázce, do jaké míry, či zdali vůbec, ovlivní výuka 3D modelování žáky v oblasti prostorové představivosti. To je důležité $\mathrm{z}$ hlediska toho, zda má vůbec smysl vyučovat žáky ve zjednodušeném programu, který se v poměrně zásadní míře liší od programů, se kterými se budou žáci potkávat $\mathrm{v}$ reálném pracovním prostředí.

\subsection{Které pojmy jsou pro naše téma důležité?}

K odpovědi na tuto otázku jsme použili zejména vyhledávání teoretických zdrojů. Mezi pojmy můžeme zařadit $3 D$ modelování, představivost, prostorová inteligence, prostorová představivost a mentální rotace. Tyto pojmy nás budou zajímat $\mathrm{v}$ souvislosti $\mathrm{s}$ výukou a ăáky. Pojem 3D tisk (tiskárny) jsme do vyhledávání nezařadili z toho důvodu, že toto zařízení bereme jako výukový prostředek pro naplnění cíle. Také by se objevily články zaměřené spíše technickým nikoliv edukativním směrem.

\subsection{Je stanovený yózkum možné provést a navazuje na nějaké předešlé?}

Zde nám opět $\mathrm{z}$ velké míry pomohlo vyhledávání teoretických zdrojů. Při tomto vyhledávaní jsme narazili na disertační práci Janovce (2011). Zabývá se obdobným výzkumem, ale ve vysokoškolském prostředí. Pro náš účel by bylo potřeba výzkum transformovat do formy vhodné pro základní školy. Kdybychom tak učinili, to znamená zejména změnit prostředek pro výuku 3D modelovaní, výzkum by za těchto podmínek odpovídal našemu návrhu.

K testování žáků chceme využít část I-S-T testu, kde nás bude zajímat zejména část zkoumající schopnosti mentální rotace. Výhodou těchto testů je, že jsou standardizovány. Obsahují výsledky pro 6. tř́du orientační a pro vyšší normované, což nám pomůže data porovnat i lépe interpretovat. Prostorová představivost se v minulosti měřila podle schopnosti mentální rotace, což dokazují i starší výzkumy již z 80. let. Jedná se zejména o práce Vandenberga a Kuse (1978), které vychází z práce Sheparda a Metzler (1971).

\subsection{Jakým způsobem probíhá výzkum našeho tématu v ČR?}

V C̆R se obdobnou problematikou zabývala zejména disertační práce Janovce (2011). Používal obdobné metody a postupy, jaké chceme ve výzkumu využít i my, s tím rozdílem, že jeho cílová skupina jsou studenti vysoké školy. V našem prostředí se též mnoho prací věnuje využití 3D modelování, ale jako prostředku pro výuku specifické problematiky. Můžeme zde uvést např́iklad výzkumy Jančaříková, Jančařík (2016, 2017), kteří zkoumají využitelnost zobrazení pomocí 3D modelů ve výuce v e-kurzech.

V databázích Web of Science a Scopus se nám nepodařilo nalézt české výzkumy zaměřené na cílovou skupinu žáků základních škol týkající se prostorové př̌edstavivosti v kontextu výuky 3D modelování. Náš výzkum bude tedy v podstatě transformace již provedeného výzkumu Janovce (2011) na základní školy. 


\subsection{Jakým způsobem probíhá výzkum našeho tématu ve světě?}

V databázích Scopus a WoS nebyla nalezena žádná publikace, která by se věnovala stejnému výzkumnému problému. Relativně prríbuzný výzkum provádí Topas, Celik a Turgce (2012), kteří se věnují kvalitě tvorby virtuálních 3D modelů. Na již vytvořený 3D model, který značně odpovídá realitě, přikládají modely žáků a následně výsledky porovnávají mezi sebou. Ostatní výzkumy berou 3D modely jako prostředek pro výuku v různých oblastech např. zdravotnictví, strojírenství, architektura, astronomie atd.

Výzkum, který provádí Toptas, Celik a Turgce (2012) je poměrně podnětný, přistupuje $\mathrm{k}$ řešení této problematiky $\mathrm{z}$ jiného úhlu pohledu. Tento výzkum může být námětem pro realizaci obdobného výzkumného šetření v našich podmínkách.

\subsection{Které publikace jsou u tohoto tématu považovány za klíčové?}

Mezi klíčové publikace můžeme zařadit ty, které nám pomohly stanovit pojmy, které jsou pro nás důležité, tedy literaturu v tabulce Tř́idění teoretických přístupů představivosti a prostorové představivosti. Jako hlavní opora z hlediska výzkumu nám poslouží disertační práce Janovce (2011). Aktuální výzkum, alespoň v podobné problematice, řeší autoři Toptas, Celik a Turgce (2012) v Řecku. Proces zkoumání prostorové představivosti a jeho historický vývoj nám osvětlí Shepard a Metzler (1971), na které navazují Vadenberg a Kuse (1978). A aktuální problematiku testování řeší Amthauer (2005). 


\section{Vyhledávání teoretických zdrojů}

Nejprve proběhlo vyhledávání teoretických zdrojů. Pro vyhledávání se využila celá řada způsobů, naprríklad: doporučení školitele, konzultanta, návštěva knihovny, hledání zdrojů na internetu a doporučení kolegů. Na první pohled se může zdát, že se jedná poměrně o nahodilou činnost, která bude mít pouze malý význam. Opak je pravdou. Kombinací takto hledaných zdrojů se nám podařilo vyhledat velké množství pro nás klíčové literatury. Tento druh hledání nám pomohl odpovědět zejména na klíčovou otázku, které pojmy jsou pro naše téma důležité.

\subsection{Srovnávací tabulky vyhledávání teoretických zdrojů.}

Srovnávací tabulky 1 a 2 obsahují třídění teoretických přístupů představivosti, prostorové představivosti a prostorové inteligence, zabývají se též rozborem prací s mentální rotací.

\begin{tabular}{|l|c|l|}
\hline Autor & Rok publikace & Problematika \\
\hline J. Kelnarová a E. Matějková & $\mathbf{2 0 1 0}$ & $\begin{array}{l}\text { Snaha o podložení faktu psychického děje } \\
\text { vedoucího ke vzniku pamětových představ. }\end{array}$ \\
\hline H. Gardner & 1999 & $\begin{array}{l}\text { Vymezení inteligence jako schopnosti řešit } \\
\text { problémy s určitou hodnotou v kulturních } \\
\text { prostředích. } \\
\text { Podrobné zpracování pojmu prostorová } \\
\text { inteligence. }\end{array}$ \\
\hline J. Průcha & 1998 & $\begin{array}{l}\text { Pojednání o systému integrace fantazie do } \\
\text { psychiky. }\end{array}$ \\
\hline J. Pelikán & 1998 & $\begin{array}{l}\text { Klasifikace obrazotvornosti (představivosti). } \\
\text { Rozdělení představivosti na matematickou, } \\
\text { geometrickou a prostorovou představivost. }\end{array}$ \\
\hline J. Čáp & 1993 & $\begin{array}{l}\text { Rozbor pojmu představivost z hlediska } \\
\text { psychologie. } \\
\text { Vliv vzniku obrazu na základě složek vlivu. }\end{array}$ \\
\hline T. A. Il'jina & 1972 & $\begin{array}{l}\text { Chápání představivosti jako produktu intelektuální } \\
\text { aktivity žáka. } \\
\text { Vliv bezprostředních dojmů na rozvoj } \\
\text { představivosti. }\end{array}$ \\
\hline
\end{tabular}

Tab. č. 1: Tabulka třidèni teoretických přistupư představivosti, prostorové představivosti a prostorové inteligence. 


\begin{tabular}{|l|c|l|}
\hline Autor & Rok publikace & Problematika \\
\hline J. Janovec & 2011 & $\begin{array}{l}\text { Pojem 3D modelování. } \\
\text { Diagnostika schopnosti prostorové } \\
\text { představivosti a schopnosti manipulovat s } \\
\text { obrazy v naší mysli. }\end{array}$ \\
\hline R. Amthauer & $\mathbf{2 0 0 5}$ & $\begin{array}{l}\text { Vyhodnocování I-S-T testu. } \\
\text { Definování figurální inteligence. }\end{array}$ \\
\hline $\begin{array}{l}\text { S. G. Vandenberg a A. R. } \\
\text { Kuse }\end{array}$ & 1978 & $\begin{array}{l}\text { Provádění výzkumu a testování založeném na } \\
\text { prostorové představivosti 3D objektů pomocí 2D } \\
\text { kreseb. }\end{array}$ \\
\hline R. N. Shepard a J. Metzler & 1971 & $\begin{array}{l}\text { Podrobný popis výsledků experimentu za } \\
\text { pomoci obrázků trojrozměrných geometrických } \\
\text { tvarů. } \\
\text { Specifikace lineární funkce umožňující } \\
\text { schopnost rotace objektem a mentálními } \\
\text { obrazy. }\end{array}$ \\
\hline
\end{tabular}

Tab. č. 2: Tabulka rozboru prací zabývajicí se mentální rotací.

\section{Vyhledávání v databázích}

Vyhledávaní v databázích je pro nás klíčové a nejlépe nám odpoví na otázku, jakým způsobem probíhá výzkum v ČR a ve světě. Pro vyhledávání jsme využili databáze Web of Science a Scopus.

\subsection{Klíčová slova}

Výběr klíčových slov úzce souvisí s klíčovými pojmy, proto se do určité míry překrývají. Stanovit systém vyhledávání přes klíčová slova je poměrně problematický. Pro naše účely jsme vytvořili následující koncepci. Pro to, aby pro nás byl článek validně vyhledán, je potřeba, aby obsahoval alespoň 3 klíčová slova. Z toho musí být alespoň jedno z klíčových slov: 3D modelování nebo výuka. Podle tohoto systému jsou i vytvořeny tabulky 3 až 5 . Mezi primární klíčová slova tedy patří 3D modelování a výuka. V kontextu našeho výzkumu je 3D modelování definováno jako tvorba trojrozměrných modelů ve virtuálním prostréedí, odchylky od tohoto pojetí pak mají vliv na relevanci vyhledaných článků.

Mezi sekundární slova následně řadíme slova: prostorová inteligence, prostorová představivost, mentální rotace a žák. Vyhledávání probíhalo v databázích, kde je nutné vyhledávat přes anglická slova, proto jsme přeložili slova do angličtiny a přiřadili jim i odpovídající ekvivalenty.

- Výuka (Teaching, Learning, Education)

- 3 D modelování (3D Modeling);

- $\quad$ Prostorová představivost (Space imagination);

- Prostorová inteligence (Spatial (figural) intelligence);

- Žák (Pupil, Student);

- Mentální rotace (Mental rotation). 
V pojmové mapě (obr. č. 1) je znázorněn vzájemný vztah mezi jednotlivými pojmy a vzájemná návaznost jednotlivých klíčových slov v kontextu nastaveného systému vyhledávání. Jako dva hlavní výrazy byly vybrány Výuka a 3D modelování. Pokud vyhledaný článek neobsahoval alespoň jedno z nich, nebyl vyhledán. Proto jsme je daly v pojmové mapě na stejnou úroveň. Souvztažnost výuky a žáka je jasná, výuka nás zajímá zejména ve vztahu k samotným žákům, u kterých zkoumáme rozvoj prostorové inteligence za pomocí právě výuky 3D modelování. Prostorová představivost je pak, dalo by se říci, podmnožinou prostorové inteligence a zkoumá se pomocí mentální rotace.

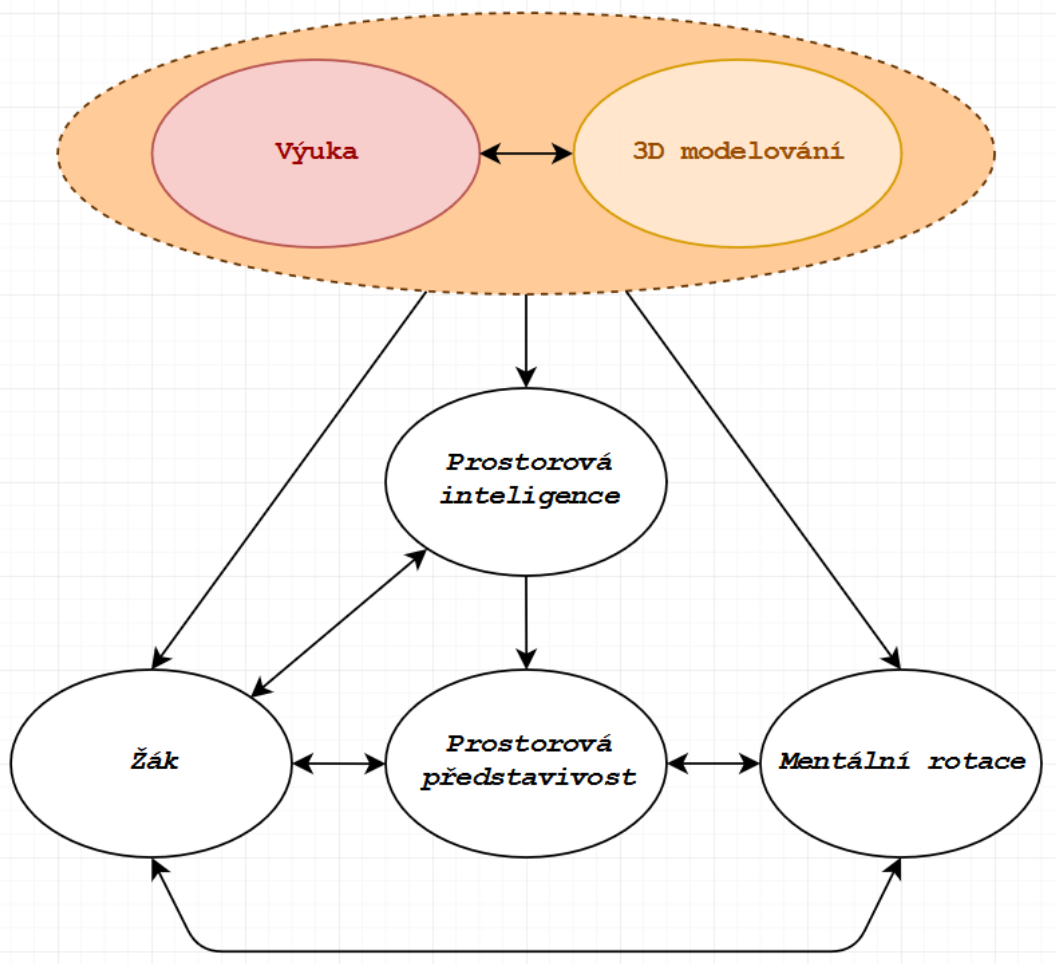

Obr. č. 1: Pojmová mapa klíčových slov. 


\subsection{Výskyt klíčových slov v databázích}

V této části se podíváme na zastoupení klíčových slov v jednotlivých databázích. Pro lepší názornost budou zobrazeny v grafech číslo 1 až 4. Jednotlivá klíčová slova jsou zobrazena jako součet jejich anglických ekvivalentů.

\section{Scopus: klíčová slova}

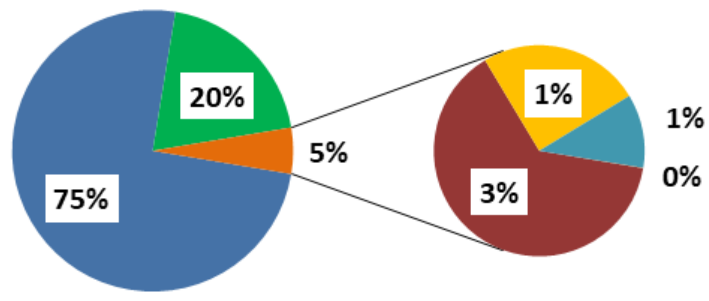

\begin{tabular}{|c|c|}
\hline - výuka & • 3D modelování \\
\hline Žák & Prostorová představivo \\
\hline Mentální rotace & - Prostorová inteligence \\
\hline
\end{tabular}

Graf č. 1: Graf výskytu klíčových slov v databázi Scopus (graf výsečový).

Na grafu č. 1 je znázorněno procentuální zastoupení jednotlivých výrazů. Můžeme si povšimnout zásadního rozdílu v poměru vyhledaných klíčových slov.

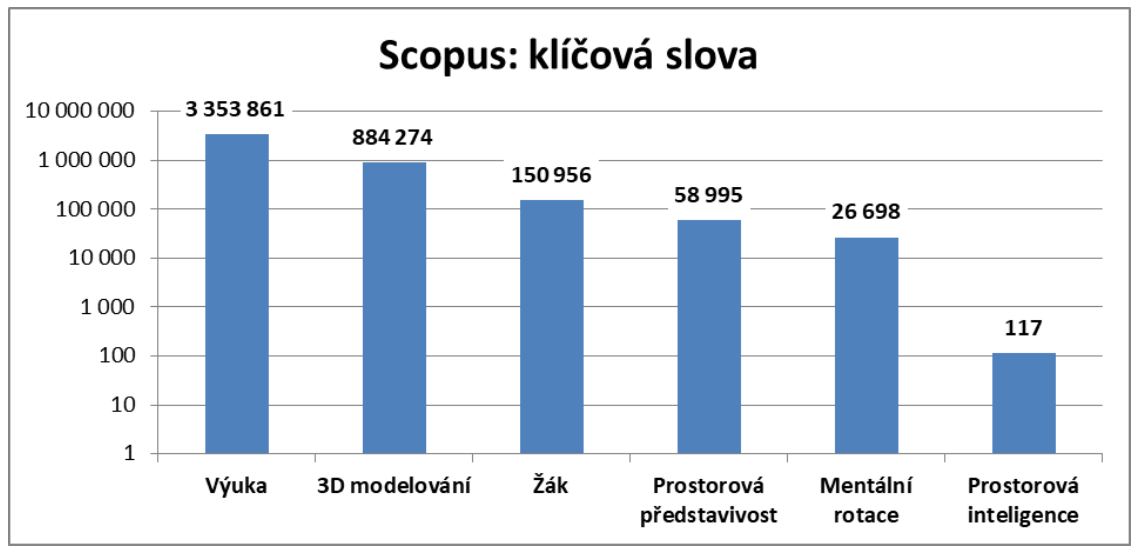

Graf č. 2: Graf výskytu klíčových slov v databázi Scopus (graf sloupcový).

V grafu č. 2 je znázorněn počet vyhledaných výrazů v celé databázi. Pro lepší přehlednost je použito logaritmické měřítko. 


\section{WoS: klíčová slova}

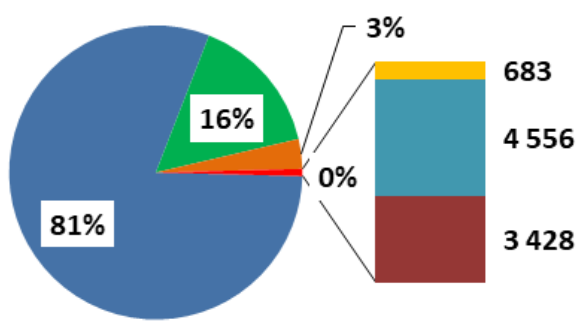

\begin{tabular}{|c|c|}
\hline - Výuka & • 3D modelování \\
\hline —Žák & — Prostorová představivost \\
\hline Mentální rotace & - Prostorová inteligenc \\
\hline
\end{tabular}

Graf č. 3: Graf výskytu kličových slov v databázi Web of Science (graf výsečový).

Na grafu č. 3 je znázorněno procentuální zastoupení jednotlivých výrazů. Pro lepší přehlednost jsou u tří nejméně vyskytujících se slov zobrazeny hodnoty, nebot' při zobrazení procentuálního zastoupení by byl popisek vždy $0 \%$.

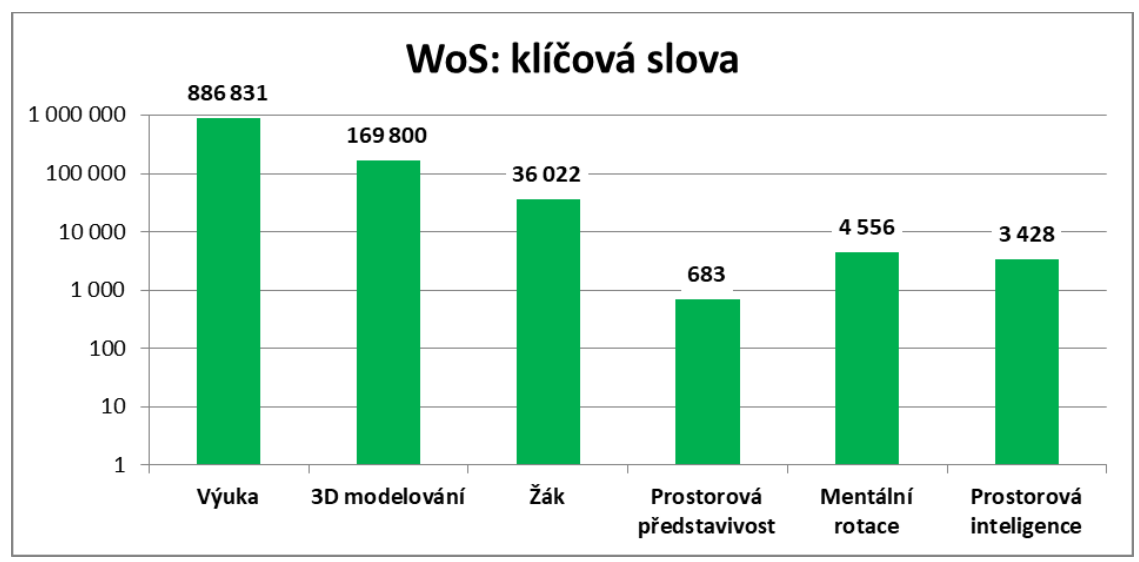

Graf č. 4: Graf výskytu klíčových slov v databázi Web of Science (graf sloupcový). 
V grafu č. 4 je znázorněn počet vyhledaných výrazů v celé databázi. Pro lepší přehlednost je použito logaritmické měřítko. Můžeme zde vidět velké rozdíly v množství vyhledaných výrazů.

\subsection{Srovnávací tabulky vyhledávání v databázích}

Srovnávací tabulky (č. 3 až 5) byly rozděleny do 3 částí podle primárních vyhledávaných slov a obsahují publikace s nejbližší možnou podobností k našemu tématu.

\begin{tabular}{|c|c|c|c|}
\hline $\begin{array}{c}\text { Vyhledávané } \\
\text { výrazy }\end{array}$ & Autor & Rok & Problematika \\
\hline \multirow{3}{*}{$\begin{array}{l}\text { Výuka; } \\
\text { 3D modelování; } \\
\text { Prostorová } \\
\text { představivost; }\end{array}$} & Smeuranu I. & 2017 & Inovativní scénáře pro snazší učení a vzdělávání. \\
\hline & Ferdiánová V. & 2016 & $\begin{array}{l}\text { Využití moderních technologií 3D modelování v pedagogickém oboru } \\
\text { matematiky a geometrie. }\end{array}$ \\
\hline & Thehub A. & 2007 & $\begin{array}{l}\text { Zpracování teorie osoby, prostoru a představivosti pro snazší formy } \\
\text { učení. }\end{array}$ \\
\hline \multicolumn{4}{|r|}{ Celkem 7 výsledků. } \\
\hline \multirow{2}{*}{$\begin{array}{l}\text { Výuka; } \\
\text { 3D modelování; } \\
\text { Prostorová } \\
\text { inteligence; }\end{array}$} & $\begin{array}{l}\text { Grossird E., } \\
\text { Talbot H. }\end{array}$ & 2017 & $\begin{array}{l}\text { Využití 3D modelování a výroby prvků z recyklovaných plastů pro } \\
\text { podporu rozvoje prostorové představivosti a inteligence. }\end{array}$ \\
\hline & $\begin{array}{l}\text { García Benítez, } \\
\text { López Molina, } \\
\text { Castellanos } \\
\text { Pedroza }\end{array}$ & 2016 & Využití 3D modelování a modelů v oblasti geologických průzkumů. \\
\hline \multicolumn{4}{|r|}{ Celkem 54 výsledků. } \\
\hline \multirow{2}{*}{$\begin{array}{l}\text { Výuka; } \\
\text { 3D modelování; } \\
\text { Žák; }\end{array}$} & \begin{tabular}{|l} 
Jančaříková K., \\
Jančařík K.
\end{tabular} & 2017 & $\begin{array}{l}\text { Rozvoj e-learningu jako formy učení za podpory použití 3D modelování } \\
\text { a tvorby elektronických učebnic. }\end{array}$ \\
\hline & $\begin{array}{l}\text { Jančaříková K., } \\
\text { Jančařík K. }\end{array}$ & 2016 & Využití dynamických modelů a 3D projekce pro rozvoj vyučování. \\
\hline \multicolumn{4}{|r|}{ Celkem 16 výsledků. } \\
\hline \multirow{3}{*}{$\begin{array}{l}\text { Výuka; } \\
\text { 3D modelování; } \\
\text { Mentální } \\
\text { rotace; }\end{array}$} & \begin{tabular}{|l|} 
Berney S., \\
Molinari G.
\end{tabular} & 2015 & $\begin{array}{l}\text { Jak využít prvky 3D modelů pro jednoduší učení a pochopení anatomie } \\
\text { a jejích učebních modelů. }\end{array}$ \\
\hline & $\begin{array}{l}\text { Qi S. , Yan Y., } \\
\text { Li R., Hu J. }\end{array}$ & 2013 & $\begin{array}{l}\text { Tvorba projektů za použití 3D modelování pro učení zubařské praxe a } \\
\text { zubní hygienistiky. }\end{array}$ \\
\hline & Ardebili M., & 2008 & $\begin{array}{l}\text { Použití 3D modelovánía dalších multimediálních softwarů pro učení } \\
\text { lepší prostorové představivosti. }\end{array}$ \\
\hline \multicolumn{4}{|r|}{ Celkem 12 výsledků. } \\
\hline
\end{tabular}

Tab. č. 3: Srovnávaci tabulka s oběma primárními kličovými slovy. 


\begin{tabular}{|c|c|c|c|}
\hline $\begin{array}{l}\text { Vyhledávané } \\
\text { výrazy }\end{array}$ & Autor & Rok & Problematika \\
\hline \multirow{2}{*}{$\begin{array}{l}\text { Výuka; } \\
\text { Prostorová } \\
\text { představivost; } \\
\text { Prostorová } \\
\text { inteligence; }\end{array}$} & $\begin{array}{l}\text { Ginn S., } \\
\text { Pickens S. }\end{array}$ & 2008 & $\begin{array}{l}\text { Vliv výuky prostorové představivosti a prostorové inteligence pro } \\
\text { podporu výuky sexuální výchovy na základních školách a lepší } \\
\text { prevence proti šírení pohlavních chorob. }\end{array}$ \\
\hline & $\begin{array}{l}\text { Lindenberg U., } \\
\text { Kliegl R., } \\
\text { Baltes P. } \\
\end{array}$ & 1992 & $\begin{array}{l}\text { Rozvoj pamětových možností pomocí prostorové představivosti a } \\
\text { prostorové inteligence jedinců v době technického rozvoje. }\end{array}$ \\
\hline \multicolumn{4}{|r|}{ Celkem 21 výsledků. } \\
\hline $\begin{array}{l}\text { Výuka; } \\
\text { Prostorová } \\
\text { představivost; } \\
\text { Žák; }\end{array}$ & $\begin{array}{l}\text { Koller A., } \\
\text { Rost J., } \\
\text { Koller M. }\end{array}$ & 1994 & $\begin{array}{l}\text { Individuální výuka prostorové představivosti za použití IST testů a její } \\
\text { vliv na žáka a jeho možnosti učení. }\end{array}$ \\
\hline \multicolumn{4}{|r|}{ Celkem 3 výsledky. } \\
\hline \begin{tabular}{|l|} 
Výuka; \\
Prostorová \\
představivost; \\
Mentální \\
rotace;
\end{tabular} & $\begin{array}{l}\text { Habacha H., } \\
\text { Molinaro C., } \\
\text { Dosseville F. }\end{array}$ & 2014 & $\begin{array}{l}\text { Efektivnost výuky žáků, jejich prostorové představivosti na sportovní } \\
\text { výkony a znalost mentální rotace objektů z kategorizace míčových her. }\end{array}$ \\
\hline \multicolumn{4}{|r|}{ Celkem 38 výsleků. } \\
\hline $\begin{array}{l}\text { Výuka; } \\
\text { Prostorová } \\
\text { inteligence; } \\
\text { Žák; }\end{array}$ & $\begin{array}{l}\text { Lopowská M., } \\
\text { Czaplewska E., } \\
\text { Wysocka A. }\end{array}$ & 2011 & Visuospatická výuka dětí a žáků s dyslexií. \\
\hline \multicolumn{4}{|r|}{ Celkem 2 výsledky. } \\
\hline \multirow{2}{*}{$\begin{array}{l}\text { Výuka; } \\
\text { Prostorová } \\
\text { inteligence; } \\
\text { Mentální } \\
\text { rotace; }\end{array}$} & $\begin{array}{l}\text { Heyden K., } \\
\text { Jolles J. }\end{array}$ & 2017 & $\begin{array}{l}\text { Využití efektu intervence třídy žáků za pomoci používání výukových } \\
\text { materiálů pro podporu prostorové představivosti. }\end{array}$ \\
\hline & $\begin{array}{l}\text { Robbins T., } \\
\text { James M., } \\
\text { Owen A., } \\
\text { Sahakian B. }\end{array}$ & 1994 & $\begin{array}{l}\text { Cambrigský neuropsychologický test automatické baterie, který } \\
\text { využivá faktory prostorové inteligence pro jednoduší pochopenía } \\
\text { následnému hodnocení. }\end{array}$ \\
\hline \multicolumn{4}{|r|}{ Celkem 8 výsledků. } \\
\hline $\begin{array}{l}\text { Výuka; Žák; } \\
\text { Mentální } \\
\text { rotace; }\end{array}$ & $\begin{array}{l}\text { Topas V., } \\
\text { Celik S., } \\
\text { Karaca E. }\end{array}$ & 2012 & $\begin{array}{l}\text { Novodobá forma učení prostorového přemýšlení a využívání 3D } \\
\text { modelovacího programu pro rozvoj mentální rotace u žáků základních } \\
\text { škol. }\end{array}$ \\
\hline
\end{tabular}

Tab. č. 4: Srovnávaci tabulka s primárním kličovým slovem výuka. 


\begin{tabular}{|c|c|c|c|}
\hline $\begin{array}{c}\text { Vyhledávané } \\
\text { výrazy }\end{array}$ & Autor & Rok & Problematika \\
\hline $\begin{array}{l}\text { 3D modelování; } \\
\text { Prostorová } \\
\text { představivost; } \\
\text { Prostorová } \\
\text { inteligence; }\end{array}$ & Harvard A. & 1998 & $\begin{array}{l}\text { Studie zaměřená na interaktivní a multimediální učební pomůcky jako } \\
\text { jsou 3D modely, testy prostorové představivosti a inteligence a } \\
\text { grafické prostorové modely v rámci hodin IT. }\end{array}$ \\
\hline \multicolumn{4}{|r|}{ Celkem 1 výsledek } \\
\hline $\begin{array}{l}\text { 3D modelování; } \\
\text { Prostorová } \\
\text { představivost; } \\
\text { Žák; } \\
\end{array}$ & Jančařík A. & 2016 & $\begin{array}{l}\text { Model učebního plánu zabývajííiho se matematickými znalostmi } \\
\text { základní školy za podpory využití 3D modelování v prítomnosti žáků. }\end{array}$ \\
\hline & & & Celkem 1 výsledek \\
\hline \multicolumn{4}{|c|}{$\begin{array}{l}\text { 3D modelování; Prostorová představivost; Mentální rotace; } \\
\text { Žádné relevantní výsledky. }\end{array}$} \\
\hline \multirow{2}{*}{\multicolumn{4}{|c|}{\begin{tabular}{|l} 
\\
3D modelování; Prostorová inteligence; Žák; \\
Žádné relevantní výsledky.
\end{tabular}}} \\
\hline & & & \\
\hline \multicolumn{4}{|c|}{ 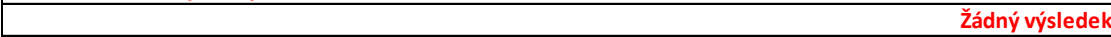 } \\
\hline \multicolumn{4}{|c|}{$\begin{array}{l}\text { 3D modelování; Prostorová inteligence; Mentální rotace; } \\
\text { Žádné relevantní výsledky. }\end{array}$} \\
\hline \multicolumn{4}{|c|}{$\begin{array}{|lc|} & \text { Žádný výsledek } \\
\end{array}$} \\
\hline $\begin{array}{l}\text { 3D modelování; } \\
\text { Žák; Mentální } \\
\text { rotace; }\end{array}$ & Ardebili M. & 2006 & $\begin{array}{l}\text { Použití 3D modelování a multimediálního softwaru pro zlepšení } \\
\text { prostorových vizualizačních dovedností. }\end{array}$ \\
\hline & & & Celkem 14 výsledků \\
\hline
\end{tabular}

Tab. č. 5: Srovnávací tabulka s primárním kličovým slovem 3D modelování.

\section{Diskuze}

Pro teoretickou oporu nám posloužila hlavně běžně dostupná literatura, mohli jsme tak lépe porozumět pojmům jako představa (Kelnarová \& Matějková, 2010), představivost (Č́p, 1993; Il'jina, 1972; Pelikán, 1998), prostorová inteligence (Gardner, 1999) a prostorová představivost (Pelikán, 1998).

Prostorová představivost se historicky zkoumala pomocí testování schopností mentální rotace. Testování bylo založeno na obrázcích trojrozměrných geometrických tvarů (Shepard \& Metzler, 1971), na tento výzkum navázali Vendenberg a Kuse (1978).

Dnes se mluví o prostorové představivosti jako součásti inteligence, Gender (1999) podrobně popisuje pojem prostorová inteligence. Amthauer (2005) operuje s pojmem figurální inteligence, který je v podstatě nadřazený prostorové př̀dstavivosti, ve svém testu struktury inteligence měří právě i škálu figurální inteligence. Náš výzkum stejně jako v disertační práci Janovce (2011), bude vycházet z tohoto testu a měřit prostorovou př̀dstavivost pomocí mentální rotace.

Chtěli jsme náš plánovaný výzkum porovnat s ostatními, což znamenalo pročíst se velkým množstvím článků. $\mathrm{V}$ databázích WoS a Scopus je celá řada článkủ, které se věnují využití 3D modelů ve výuce, at již například ve vzdělávání (Jančaříková \& Jančařík, 2016, 2017) nebo specifickém oboru jako například geologie (García Benítez, López Molina \& Castellanos Pedroza, 2016), sport (Habacha, Molinaro \& Dosseville, 2014), matematika 
(Fardiánová, 2016), zdravotnictví (Berney, Bértracourt, Milinari \& Hoynek, 2015), atd. Publikace byly mnohdy podnětné, ale neshodovaly se přesně s tím, co chceme zkoumat, tedy vlivu výuky 3D modelování na prostorovou představivost. Mezi nejprínosnější publikace můžeme zařadit řecký článek autorů Toptas, Çelik a Karaca (2012), který popisuje výzkum vedený u žáků základních škol. Tento výzkum se věnuje porovnávání vytvořených modelů $\mathrm{s}$ předlohou. Můžeme tedy říci, že náš plánovaný výzkum bude originální a zároveň přínosný.

\section{Závěr}

Přehledová studie vznikla na základě potřeby dohledání ucelených podkladů pro plánovaný výzkum Vliv 3D modelování na prostorovou představivost. Mezi hlavní části přehledové studie patří popis měrného nástroje, ve kterém je představen plánovaný výzkum. Na základě tohoto výzkumu byly sestaveny klíčové otázky přehledové studie. Odpovědi na klíčové otázky byly vytvořeny na základě vyhledaných publikací. Další části se věnují hlavně vyhledávání zdrojů. Pro vyhledávání teoretických zdrojů byla využita celá řada způsobů, např́klad: doporučení školitele, konzultanta, návštěva knihovny, hledání zdrojů na internetu a doporučení kolegů. Toto vyhledávání bylo důležité pro stanovení důležitých pojmů. Do značné míry odpovídalo na možnost realizace výzkumu a částečně odpovídalo na otázky, jakým způsobem se provádí výzkum v ČR a zahraničí. Vyhledávání v databázích plnilo zejména kontrolní funkci. Odpovídalo též na otázky, zda náš výzkum na nějaký navazuje a jakým způsobem se obdobné výzkumy provádí.

\section{Literatura}

Amthauer, R., Burkhard, B., Liepmann, D. \& Beaducel, A. (2005). Test struktury inteligence I-S-T 2000 R: Príručka. Praha: Testcentrum.

Ardebili, M. (2006). Usin solid modeling and multimedia software to improve spatialvisualization skills, ASEE Annual Conference and Exposition, Conference Proceedings.

Berney, S., Bértracourt, M., Milinari, G. \& Hoynek, N. (2015). How spatial abilities and dynamic visualizations interplay when learning functional anatomy with $3 D$ prjection and 3D anatomical models, Anatomical Sciences Education, 452-462.

Čáp, J. (1993). Psychologie výchovy a vyučování. Praha: Karolinum.

Fardiánová, V. (2016). Using anaglyphs in descriptive geometry, Proceedings of the European Conference on e-Learning, ECEL, 194-200.

Gardner, H. (1999). Dimenze myšleni: teorie rozmanitých inteligencí. Praha: Portál.

García Benítez, S. R., López Molina, J. A., \& Castellanos Pedroza, V. (2016). Neural networks for defining spatial variation of rock properties in sparsely instrumented media. Boletin De La Sociedad Geologica Mexicana, 68(3), 553-570. doi:10.18268/BSGM2016v68n3a10

Ginn, S. R. \& Pickens, S. J. (2005). Relationship between spatian activities and scores of mental rotation test as a function of sexual lessons, Perceptual and Motor Skills, 877-881. Grossiord, E. \& Talbot, H. (2017). Automated 3D lymphoma lesion segmentation from PET/CT characteristics, Proceedings - International Symposium on Biomedical Imaging, 174-178.

Habacha, H., Molinaro, C., \& Dosseville, F. (2014). Effects of gender, imagery ability, and sports practice on the performance of a mental rotation task. American Journal of Psychology, 127(3), 313-323. doi:10.5406/amerjpsyc.127.3.0313 
Harvard, A. (1998). Go - v originále [Gå], Human IT.

Heyden, K. M. V. \& Jolles, J. (2017) Effects of a classroom intervention with spatial play materials on children's object and viewer transformation abilities, Developmental Psychology, 290-305.

Janovec, J. (2011). Počitačem podporovaná konstruktivní geometrie. Univerzita Hradec Králové (Disertační práce).

Il'jina, T. A. (1972). Pedagogika: učebnice pro posluchače pedagogických institutů. Praha: Státní pedagogické nakladatelství.

Jančař́k, A. (2016). Dynamic models using 3D projection, Proceedings of the European Conference on e-Learning, ECEL, 296-304.

Jančaříková, K. \& Jančařík, A. (2016). Work with 3D models in e-learning environments, Proceedings of the European Conference on e-Learning, ECEL, 305-314.

Jančaříková, K. \& Jančařík, A. (2017). Teaching aids and work with models in e-learning environments, Electronic Journal of e-Learning, 244-258.

Kelnarová, J. \& Matějková E. (2010). Psychologie: pro studenty zdravotnických oborů. Praha: Grada.

Koller, O., Rost, J. \& Koller, M. (1994). Individual differences in solving spatial problems of the IST and IST-70 subtest on "cube problems, Zeitschrift fur Psychologie, 65-85.

Krotký, J., Honzíková, J. \& Moc, P. (2016). Deformation of Print PLA Material Depending on the Temperature of Reheating Printing Pad. Manufacturing Technology. Ústí nad Labem: UJEP, FVTM. Vol. 16, No 1, 140-144.

Lindenberger, U., Kliegl, R., \& Baltes, P. B. (1992). Professional expertise does not eliminate age differences in imagery-based memory performance during adulthood. Psychology and Aging, 7(4), 585-593.

Pelikán, J. (1998). Základy empirického výzkumu pedagogických jevů. Praha: Karolinum. Průcha, J., Walterová, E. \& Mareš, J. (1998). Pedagogický slovník. 2. rozš. a přeprac. vyd. Praha: Portál.

Qi, S., Yan, Y., Li, R. \& Hu, J. (2013). The impact of active versus passive use of 3D technology for students of dental university in China, Journal of Dental Education, 1536-1542.

Robbins, T. W., James, M., Owen, A. M., Sahakian, B. J., Mclnnes, L. \& Rabbit, P. (1994). Cambridge neuropsychological test automated battery (CANTAB): A factor analytic study of a large sample of normal elderly volunteers, Dementia, 266-281.

Shepard, R. N. \& Metzler, J. (1971). Mental Rotation of Three-Dimensional Objects. Science [online]. 171(3972), 701-703 [cit. 2017-06-18]. DOI: 10.1126/science.171.3972.701.

Smeureanu, I. (2017). Innovative educational screnarios in game based teaching and learning, Amfiteatru Economic, 890-899.

Thehub, A. (2007). Space, self, and the theater of concinousness, Consciousness and cognition, 890-899.

Toptas, V., Çelik, S. \& Karaca, E. T. (2012). Improving 8th Grades Spatial Thinking Abilities through a $3 D$ Modeling Program. TOJET: The Turkish Online Journal of Educational Technology, 128-134.

Vandenberg, S. G. \& Allan R. K. (1978). Mental rotations, a group test of threedimensional spatial visualization. Perceptual and Motor Skills. 47(2), 599-604. DOI: 10.2466/pms.1978.47.2.599. 